УДК 159.923/.928 - 057.875

Б. І. ОНІСКОВЕЦЬ, О. Г. СТАВИЦЬКА

\title{
МОТИВАЦІЙНІ ЧИННИКИ ПЕРФЕКЦІОНІЗМУ СУЧАСНОЇ СТУДЕНТСЬКОЇ МОЛОДІ
}

Стаття присвячена аналізу мотиваційних чинників, що сприяють розвитку перфекиіонизму у сучасної студентської молоді. Проведено теоретичний аналіз вітчизняних та зарубіжних наукових досліджень генези перфекиіонізму. Проаналізовано базові форми та основні механізми утворення даного психологічного конструкту. На основі узагальнення даних, виокремлено мотивачійні фактори, що сприяють розвитку перфекиіонізму у студентської молоді. Розкрито особливість конструктивного та деструктивного перфекціонізму. Досліджено вектори впливу феномену перфекиіонізму на різні сфери життя особистості, зокрема на професійне самовизначення, міжособистісні зв'язки та сочіальну адаптацію особистості.

Ключові слова: перфекиіонізм, психологічний конструкт, мотивачія, чинник, феномен, студентська молодь, особистість, соиіальна адаптація, міжособистісні зв'язки.

Статья посвящена анализу мотивачионных факторов, способствующих развитию перфекционизму в современной студенческой молодежи. Проведен теоретический анализ отечественных и зарубежных научных исследований генезиса перфекиионизма. Проанализированы базовые формы и основные механизмы образования данного психологического конструкта. На основе обобщения данных, выделены мотивационные факторы, способствующие развитию перфекиионизма у студенческой молодежси. Раскрыто особенность конструктивного и деструктивного перфекиионизма. Исследовано векторы влияния феномена перфекиионизма на различные сферы жизни личности, в частности на профессиональное самоопределение, межличностные связи и социальную адаптацию личности.

Ключевые слова: перфекиионизм, психологический конструкт, мотивация, фактор, феномен, студенты, личность, социальная адаптация, межличностные связи.

Постановка проблеми. Сучасне суспільство нестримно розвивається, змінюється соціальнокультурна ситуація, підвищуються вимоги до кожної особистості, зростає конкуренція, панує культ самовдосконалення. За таких умов, сучасна студентська молодь прагне відповідати стандартам, що культивуються соціумом. У результаті, перфекціонізм стає характерною рисою молоді. Відомо, що студентський вік є головним у професійному становленні особистості, відбувається професійна самоідентифікація та формування життєвої стратегії, розуміння власного майбутнього, побудова певних планів на власне життя. В той же час, активно формуються такі якості, як переконання, ідеали, цінності, установки. Молода особистість невпинно удосконалюється, чітко окреслюється Випуск 11, 2018. Збірник наукових праць РДГУ 
життєва картина, позиція, яку індивід транслює в соціумі в подальші життєві роки. Відповідно, вкрай важливим фактором якісного та продуктивного життя кожної особистості, $\epsilon$ професійне самовизначення та сформовані особистісні конструкти в студентські роки.

Перфекціонізм - багатогранний конструкт, що несе у собі як і позитивні тенденції, так i дисфункційну природу. Для молодої особистості негативна тенденція перфекціонізму є загрозливим явищем, адже виникаюче почуття неповноцінності та вразливості призводить до сильних деформацій особистості та патологічних змін психічного здоров'я. Питання перфекціонізму $є$ актуальним та складним явищем, адже поєднує в собі безліч елементів, що можуть мати як конструктивну, так i патологічну значимість. Виникаючи у студентської молоді, має дві сторони відображення, перша високий рівень домагань та особистісних стандартів, активна життєва позиція, висока продуктивність, тощо. Друга - вразливість, ворожість, агресивність, занижена самооцінка, постійна емоційна напруга, безкінечне намагання досягти ідеалу. Враховуючи тиск сучасного суспільства, швидку зміну соціальних еталонів, існування високих суспільних ідеалів ризик розвитку негативних тенденцій перфекціонізму є надзвичайно високий. Проблема студентського перфекціонізму та власне мотиваційних чинників його виникнення $є$ мало дослідженою, а отже потребує якісних напрацювань в цьому напрямку.

Аналіз останніх досліджень та публікацій. Дослідження перфекціонізму набуло сили у 60 х pp. зарубіжними дослідниками (А. Бек, Р. Блатт, Д. Барнс, Л. Сільверман, Р. Слейні, Л. Террі-Шорт, Р. Фрост, Г. Флетт, Д. Хамачек, ін.). Російські дослідники також цікавилися даним явищем, і активно вивчали (Н. Гаранян, С. Еніколопов, Є. Ільїн, А. Холмогорова, В. Циганкова, Т. Юдєєва, В. Ясная та ін.). Вагомий внесок зробили і вітчизняні вчені (І. Гуляс, Л. Данилевич, Т. Завада, М. Коваленко, О. Кононенко, А. Лазько, О. Лоза, В. Павлова, Г. Чепурна та ін.) [5; с.418].

Формування цілей статті. На основі теоретичного аналізу та узагальнення даних наукових досліджень визначити особливості розвитку мотиваційних чинників перфекціонізму, та вектори впливу даного конструкту на формування особистісних якостей у сучасної студентської молоді в цілому.

Виклад основного матеріалу дослідження. Перфекціонізмом називають феномен, при якому особистість намагається досягти досконалості, найкращого результату у всіх сферах свого життя, за будь - яких умов та обставин. Зазвичай даний конструкт прийнято сприймати як позитивне явище, адже індивід воліє до високих досягнень, переборює зовнішні та внутрішні перепони, демонструє надзвичайну працездатність. Але існуючі дослідження чітко окреслюють, що перфекціонізм має кілька напрямків, і за несприятливих умов перетворюється у патологічний конструкт, який приносить особистості не тільки досягнення, а й внутрішній дискомфорт, плеяду психологічних порушень, проблеми у відносинах 3 навколишніми, та викривлення само сприйняття та зовнішнього світу (сприйняття соціуму як ворожого, внутрішня агресія). Т. Ю. Юдеєва зазначала, що перфекціонізм, як дисфункціональна особистісна риса має складну психологічну структуру, що містить поряд 3 високими стандартами діяльності й домаганнями параметри когнітивних викривлень: сприйняття інших людей як таких, що делегують високі очікування, постійне порівняння себе з оточуючими, дихотомічна оцінка результату діяльності та ії планування за принципом "все або нічого" [6, с. 275].

Сучасний стан досліджень даного конструкту вказує на те, що трактування поняття перфекціонізму є неоднозначним, хоч і існують поодинокі наукові праці у вузькому аспекті [3, с.43]. У психології, поняття перфекціонізму зазвичай ототожнюють 3 мотивацією досягнення (Дж. Аткінсон). Проте, перфекціонізм вимагає не просто досягати успіху, а досягати ідеалу і досконалості. Відповідно на даний час експерти-психологи відстоюють багатовимірну структуру даної риси особистості $[4$, с. 30]. В основу канадської концепції перфекціонізму покладена так звана об'єктна спрямованість, складовими якої є: "Я-адресоване", адресоване іншим, адресоване світу і соціальноприписуваний перфекціонізм. Г. Чепурна вважає, що соціально прописаний перфекціонізм та перфекціоністська самопрезентація, зумовлена потребою здаватися досконалим перед суспільством [5, c. 418].

Беручи до уваги ідеали та стандарти сучасного світу, можна сказати що перфекціоністські риси характерні для культури нарцисизму, де на передній план виходить споживча, маніпулятивна потреба особистості. Тобто відбувається знецінення духовного, а за основу приймається зовнішній вигляд, матеріальні статки, положення в суспільстві тощо. Для культури нарцисизму характерні висока швидкість соціально-політичних і економічних змін, нестабільність суспільних еталонів якості життя, парадоксальна поверховість захоплень, еклектичність світоглядних позицій і моральних зразків, які в цілому створюють велику спокусу для публіки і розмивають внутрішньо особистісні норми. Тому така якість індивіда, як перфекціонізм не є рідкісним явищем. Особливо піддатлива до даного конструкту сучасна молодь. А. Адлер, австрійський психіатр i психолог, трактує 
перфекціонізм як компенсаторне прагнення до переваги і досконалості [1, с. 256]. Відповідно, при позитивній тенденції перфекціонізму, особистості притаманні такі риси, як відповідальність, надійність, можливість виконання великого обсягу роботи, позитивна позиція у житті. При прояві патологічної форми - ворожість, чутливість, страх невдач, що призводить до розладів афективного спектру. А. Адлер вказував, що почуття неповноцінності стимулює до прагнення підвищити власну самооцінку, а відповідно породжує почуття до переваги [1, с. 256]. Д. Хамачек виділяє дві форми перфекціонізму - адаптивну та дезадаптивну. При адаптивній формі, особистість при високих досягненнях, зберігає право на помилку, потреба в схваленні сприймається лише як додатковий стимул. Дезадаптивній формі властива - сильна тривога, страх невдачі, сором поразки, їх не залишає відчуття, що можна було б зробити краще, звідси ж постійне незадоволення результатом.

Мотиваційними чинниками даного явища виступають безліч факторів, як особистісних, так i суспільних: потреба у схваленні та визнанні оточенням, прагнення до соціального престижу та схваленні, прагнення до психологічного комфорту, мотив досягнення успіху та уникнення невдачі, підвищена моральна відповідальність. За А. Распоповою, на розвиток перфекціонізму найбільше впливають: мотивація досягнення успіху та уникнення невдач, локус контролю, схильність до консерватизму й конформізму [5, с. 171]. С. В. Волікова, проводячи дослідження перфекціонізму, виокремила залежність високого рівня перфекціонізму та мотивації досягнення. За результатами С. В. Волікової, студентська молодь, що має високий рівень перфекціонізму, має підвищений рівень депресії, тривожності, соціальної відстороненості [2, с.23]. Відповідно, існує чітка залежність явища перфекціонізму з потребами індивіда досягати успіхів і уникати невдач. Як наслідок, відбувається вплив на емоційну сферу особистості, зазвичай негативно. Науковець В. В. Грандт стверджує, що виникнення перфекціонізму можливе на чотирьох рівнях: внутрішньоособистісному; мікросоціумі (сім’я); соціальному середовищі; макросоціумі (культура, 3МІ) [3, с.30].

Надмірне прагнення до успіху, страх невдач, дотримання сучасних високих ідеалів, прагматичність, раціональність призводять до протилежного результату, а саме - загальмовування розвитку особистості, неспроможності у прийнятті рішень, відсутності спонтанності та креативності. Завищені домагання є важливим чинником становлення молоді ауто деструктивними та адиктивними особистостями [6, с. 418]. Сучасна молода особистість повинна керуватися не викривленими ідеалами соціуму, а власними духовними ідеалами, що сформувалися від власного саморозвитку, хоч і під впливом власне соціуму. Іншими словами, повинна існувати духовна парадигма - стійкі ціннісні смислові орієнтації, здатність до переструктурування власного ментального досвіду, розвинене почуття ідентичності, рефлексії тощо [7, с. 35].

Як вважають П. Р. Гаранян, А. Б. Холмогорова і Т. Ю. Юдеєва, "перфекціонізм" являє собою складне психологічне утворення, що включає наступні параметри:

1. Завищений рівень домагань, порівняно з індивідуальними можливостями, складність цілей - надмірні вимоги до себе в плані кількості роботи та якості іï виконання, бездоганної поведінки, володіння собою в тій чи іншій ситуації, наявності різноманітних умінь і душевних якостей. Завищена складність цілей виявляється у багатьох переконаннях депресивних i тривожних особистостей: "Я завжди повинна добре виглядати", "За що б не взявся, я повинен домагатися блискучих результатів", "Помилки і невдачі - ознака некомпетентності" і т. д.

2. Поляризована, "чорно-біла" оцінка результату власної діяльності - недиференційовані судження про результати власної діяльності: "Якщо не впорався блискуче, значить, не впорався взагалі", "Якщо в ході виконання роботи я відчував труднощі, значить, це був неуспіх". Поєднання завищених домагань і поляризованого мислення може бути причиною серйозних життєвих проблем.

3. Перевага зосередженості особи на невдачах і помилках при ігноруванні реальних успіхів i досягнень. Значення невдачі сильно перебільшується, при цьому успіх знецінюється або приписується зовнішнім, незалежним від особистості обставинам. Негативізм такого роду може стосуватися як поточної діяльності, так і поширюватися на все життя. [3, с.43].

4. Перманентне порівняння себе 3 іншими людьми за умови орієнтації на полюс "найуспішніших і досконалих". Багато особистостей проживають життя в режимі порівняння себе 3 іншими людьми, відчуваючи при цьому болісне відчуття власної "меншовартості і неспроможності" (за принципом "чужі досягнення - свідчення моєї неспроможності"). Для порівняння, як правило, обираються найбільш гідні особистості, що багато чого досягли, найталановитіші, а на інших навіщо дивитися?". Наслідки таких порівнянь - перманентне почуття заздрості, невдоволення собою, хибні життєві вибори, конкурентні установки у спілкуванні, уникнення контактів, в підсумку самотність.

5. Відчуття власної невідповідності позитивним уявленням інших людей про себе, постійне передчуття публічного викриття. Ситуації успіху можуть обертатися для таких особистостей 
переживаннями тривоги і відчаю: "Знову обдурила. Тепер доведеться постійно підтверджувати цей результат, інакше - розчарую людей" [7, с. 275].

6. Оцінка багатьох нейтральних ситуацій 3 позиції рівня своїх досягнень. Відчуття невдоволення собою у зовсім несподіваних, нейтральних для самооцінки ситуаціях. Книги, фільми, твори мистецтва наносять "нарцистичні травми", оскільки вони нагадують про власну недосконалість.

7. Надмірні вимоги до інших та завищені від них очікування, наприклад: "Друг повинен приходити до мене завжди, коли мені погано, без мого виклику", "Справжній друг повинен проводити зі мною абсолютно весь вільний час дня і ночі", "Якщо мій друг розмовляє з ким-небудь, $\mathrm{i}$ взагалі спілкується з будь-якою третьою особою, - я йому не потрібна", "Мій друг не повинен хворіти або проявляти якісь ще слабкості, тому, що він мені - опора" [2, с. 544 ].

На думку П. Р. Гаранян, А. Б. Холмогорової і Т. Ю. Юдеєвої, наслідки перфекціонізму для емоційного стану юної особистості, як правило, зводяться до частих, часом хронічних, переживань незадоволеності собою; туги (через неможливість втілити у життя нездійсненно важкі цілі); тривоги, пов'язаної з очікуванням помилки, невдачі, "публічного викриття" тощо); відчуття сорому та провини $[4$, c. 43$]$.

Наслідки перфекціонізму у сфері продуктивності діяльності також можуть бути різноманітними: а) поведінка уникнення; б) стан "паралічу" як блокада активності внаслідок заборони на будь-який результат, що відрізняється від ідеального; в) зниження продуктивності й хронічна перевтома внаслідок дії фактору генералізації високих стандартів у всіх сферах діяльності (наприклад, у навчанні, домашніх справах тощо) і неможливості виділити пріоритетні завдання. Що стосується наслідків перфекціонізму у сфері міжособистісних контактів, то вони можуть бути наступні: а) конфлікти і припинення взаємин із людьми через надмірні вимоги і очікування з боку інших людей; б) конкурентні відносини із людьми через часті порівняння себе з ними і заздрощі; в) дефіцит близьких і довірливих взаємин" [3, с. 23].

У багатьох дослідженнях, як зарубіжних так і вітчизняних науковців, соціально приписаний перфекціонізм виступає негативним фактором соціальної адаптації та самоактуалізації молоді. Встановлено позитивні кореляції соціально приписаного перфекціонізму з неприйняттям себе і свого тілесного Я, з конформністю, депривованістю психологічного простору, екстернальним локусом контролю, вираженою потребою у схваленні, прокрастинацією, страхом негативної оцінки з боку інших за неможливість бути досконалим, почуттям безнадії, пасивною агресивністю, соціальною фобією, емоційним дискомфортом, депресією та іншими негативними емоційними станами [3, с. 15].

Дослідники О. Соколова та П. Циганкова відмічають у молоді з високим рівнем соціально приписаного перфекціонізму перевагу егоцентричних цінностей над абстрактними. Цю тенденцію вчені називають проявом "парадоксальної перфекціоністської мотивації", коли при наявності залежності від оцінок та думок оточуючих спостерігається прояв егоцентричності та концентрації інтересу виключно на власному Я. Визначено й певні відмінності прояву соціально приписаного перфекціонізму залежно від статі досліджуваних. Зокрема, у юнаків вищий ніж у дівчат зв'язок соціально приписаного перфекціонізму з агресією та антисоціальною поведінкою [8]. Особливо небезпечним $є$ підтвердження зв'язку соціально приписаного перфекціонізму 3 суїцидальною поведінкою молоді [9, с.178].

Отже, явище перфекціонізму має складну природу, розвиток якого зумовлюється групою чинників: особистісними (потребами, мотивами), сім'єю, соціумом, культурою. На особистісному рівні важливе значення мають потреби у комфорті, визнанні, страх бути знехтуваним, бажання здаватися досконалим, установка на результат, консерватизм та конформізм.

Висновки 3 даного дослідження i перспективи подальших розвідок. На основі теоретичного аналізу та узагальнення наукових першоджерел можна зробити наступні висновки:

1. Найпоширеніші дві форми перфекціонізму - адаптивна та дезадаптивна. При адаптивній формі, особистість при високих досягненнях, зберігає право на помилку, потреба в схваленні сприймається лише як додатковий стимул. Дезадаптивній формі властива сильна тривога, страх невдачі, сором поразки, їх не залишає відчуття, що можна було б зробити краще, звідси ж постійне незадоволення результатом.

2. Надмірне прагнення до успіху, страх невдач, дотримання сучасних високих ідеалів, прагматичність, раціональність призводять до протилежного результату, а саме - загальмовувати розвиток особистості, неспроможності у прийнятті рішень, відсутності спонтанності та креативності.

3. Мотиваційними чинниками даного явища виступають безліч факторів, як особистісних, так і суспільних: потреба у схваленні та визнанні оточенням, прагнення до соціального престижу та схваленні, прагнення до психологічного комфорту, мотив досягнення успіху та уникнення невдачі, 
підвищена моральна відповідальність.

4. Студентська молодь, що має високий рівень перфекціонізму, має підвищений рівень депресії, тривожності, соціальної відстороненості. Відповідно, існує чітка залежність явища перфекціонізму з потребами індивіда досягати успіхів і уникати невдач. Як наслідок відбувається вплив на емоційну сферу особистості, зазвичай негативно.

5. На розвиток перфекціонізму найбільше впливають: мотивація досягнення успіху та уникнення невдач, локус контролю, схильність до консерватизму й конформізму лідерськими якостями, лідерських якостей та низькою самооцінкою.

\section{Список використаних джерел}

1. Адлер А. Практика и теория индивидуальной психологии / А. Адлер. - М. : Прогресс, 1997. $-256 \mathrm{c}$.

2. Бек А. Когнитивная психотерапия расстройств личности / А. Бек, А. Фримен. - СПб. : Питер, $2002-544$ с.

3. Варлашкина Е. А. Перфекционизм как личностная детерминанта отношения к внешности / Е. А. Варлашкина, Л. И. Дементий // Психологический вестник Уральского государственного университета. - Екатеринбург : Изд-во Урал. ун-та, 2010. - Вып. 9. - С. 15.

4. Воликова С. В. Родительский перфекционизм - фактор развития эмоциональных нарушений у детей, обучающихся по усложненным программам / С. В. Воликова, А. Б. Холмогорова, А. М. Галкина // Вопросы психологии. - 2006. - № 5. - С. 23.

5. Гаранян Н. Г. Перфекционизм и враждебность как личностные факторы депрессивных и тревожных расстройств : автореф. дис. ... д-ра психол. наук : 19.00 .04 - Медицинская психология / Н. Г. Гаранян. - М., 2010. - 43 с.

6. Грандт В. В. Генезис перфекціонізму: теоретична експлікація проблеми / В. В. Грандт // Проблеми сучасної психології : зб. наук. пр. Держ. вищ. навч. закл. «Запор. нац. ун-т» та Ін-ту психології ім. Г. С. Костюка НАПН України / за ред. : С. Д. Максименка, Н. Ф. Шевченко, М. Г. Ткалич. - Запоріжжя : ЗНУ, 2014. - № 1 (5). - С. 30.

7. Распопова А. С. Особенности взаимосвязи перфекционизма и личностных свойств спортсменов / А. С. Распопова // Материалы Всероссийского форума «Молодые учёные - 2010». М. : Физ. культура, 2010. - С. 171.

8. Соколова Е. Т. Структура перфекционной мотивации у лиц с нарушением адаптации и суицидальным поведением [Электронный ресурс] / Е. Т. Соколова, П. В. Цыганкова // Психологические исследования. - 2011 - № 5 (19). - Режим доступа: http://www.psystudy.ru/index.php/num/2011n5-19/551-sokolova-tsygankova19.html. - Название с экрана.

9. Холмогорова А. Б. Нарциссизм, перфекционизм и депрессия / А. Б. Холмогорова // Московский психотерапевтический журнал. - 2004. - № 1. - С. 35.

10. Чепурна Г. Л. Перфекціонізм як чинник соціальної активності молоді / Г. Л. Чепурна // Вісник Чернігівського державного педагогічного університету імені Т. Г. Шевченка. Серія "Психологічні науки". - Чернігів : ЧДПУ, 2009. - Вип. 74, т. II. - С. 178.

11. Юдеева Т. Ю. Перфекционизм как личностный фактор депрессивных и тревожных расстройств : автореф. дис. ... канд. психол. наук : 19.00.04 / Т. Ю. Юдеева. - М., 2007. - 275 с.

\section{References}

1. Adler A. Praktika i teorija individual'noj psihologii / A. Adler. - M. : Progress, 1997. - $256 \mathrm{~s}$.

2. Bek A. Kognitivnaja psihoterapija rasstrojstv lichnosti / A. Bek, A. Frimen. - SPb. : Piter, 2002 $-544 \mathrm{~s}$.

3. Varlashkina E. A. Perfekcionizm kak lichnostnaja determinanta otnoshenija k vneshnosti / E. A. Varlashkina, L. I. Dementij // Psihologicheskij vestnik Ural'skogo gosudarstvennogo universiteta. Ekaterinburg : Izd-vo Ural. un-ta, 2010. - Vyp. 9. - S. 15.

4. Volikova S. V. Roditel'skij perfekcionizm - faktor razvitija jemocional'nyh narushenij u detej, obuchajushhihsja po uslozhnennym programmam / S. V. Volikova, A. B. Holmogorova, A. M. Galkina // Voprosy psihologii. - 2006. - № 5. - S. 23.

5. Garanjan N. G. Perfekcionizm i vrazhdebnost' kak lichnostnye faktory depressivnyh i trevozhnyh rasstrojstv : avtoref. dis. ... d-ra psihol. nauk : 19.00 .04 - Medicinskaja psihologija / G. N. Garanjan. - M., 2010. - 43 c.

6. Grandt V. V. Genezy`s perfekcionizmu: teorety`chna eksplikaciya problemy` / V. V. Grandt // Problemy` suchasnoyi psy`xologiyi : zb. nauk. pr. Derzh. vy`shh. navch. zakl. «Zapor. nac. un-t» ta In-tu 
psy`xologiyi im. G. S. Kostyuka NAPN Ukrayiny`/ za red. : S. D. Maksy`menka, N. F. Shevchenko, M. G. Tkaly`ch. - Zaporizhzhya : ZNU, 2014. - № 1 (5). - S. 30.

7. Raspopova A. S. Osobennosti vzaimosvjazi perfekcionizma i lichnostnyh svojstv sportsmenov / A. S. Raspopova // Materialy Vserossijskogo foruma «Molodye uchjonye - 2010». - M. : Fiz. kul'tura, 2010. -S. 171.

8. Sokolova E. T. Struktura perfekcionnoj motivacii u lic s narusheniem adaptacii i suicidal'nym povedeniem [Jelektronnyj resurs] / E. T. Sokolova, P. V. Cygankova // Psihologicheskie issledovanija. 2011 - № 5 (19). - Rezhim dostupu : http://www.psystudy.ru/index.php/num/2011n5-19/551-sokolovatsygankova19.html. - Nazvanye z ekrana.

9. Holmogorova A. B. Narcissizm, perfekcionizm i depressija / A. B. Holmogorova, N. G. Garanjan // Moskovskij psihoterapevticheskij zhurnal. - 2004. - № 1. - S. 35.

10. Chepurna G. L. Perfekcionizm yak chy`nny`k social`noyi akty`vnosti molodi / G. L. Chepurna // Visny`k Chernigivs`kogo derzhavnogo pedagogi`chnogo universy`tetu imeni T. G. Shevchenka. Seriya "Psy`xologichni nauky`". - Chernigiv : ChDPU, 2009. - Vy`p. 74, t. II. - S. 178.

11. Judeeva T. Ju. Perfekcionizm kak lichnostnyj faktor depressivnyh i trevozhnyh rasstrojstv : avtoref. dis. ... kand. psihol. nauk : 19.00.04 / T. Ju. Judeeva. - M., 2007. - 275 s.

\section{YOUTH}

\section{B.I. Oniskovets MOTIVATED FACTORS OF PERFECTIONISM MODERN STUDENT}

The article is devoted to the analysis of the motivational factors contributing to the development of perfectionism in modern student youth. A theoretical analysis of domestic and foreign scientific researches of the nature of perfectionism is conducted. The basic forms and basic mechanisms of formation of this psychological construct are analyzed. On the basis of data generalization, the motivational factors that promote the development of perfectionism in the students' students are singled out. The feature of constructive and destructive perfectionism is revealed. The vectors of influence of the phenomenon of perfectionism on various spheres of personality life, in particular on professional self-determination, interpersonal connections and social adaptation of the person, are investigated.

Key words: perfectionism, psychological construct, motivation, factor, phenomenon, student youth, personality, social adaptation, interpersonal connections. 